and low and declining accumulation rates. The authors view this structural decline as potentially quite ominous, which could prefigure the emergence of a serious dollar crisis and the eventual demise of US global hegemony. The diagnosis of the structural causes of the crisis lends itself to several possible future scenarios in a post-neoliberal social order:

A likely list of the developments that would stimulate new dynamics is as follows: (1) the weakness of the economic recovery and the likelihood of a new contraction of GDP, (2) the threat of the repetition of a new episode of financial perturbations, (3) a crisis of the dollar, and (4) the multiplication of new symptoms of the lost economic pre-eminence of the US (237).

The only real criticism proposed is that the authors have inexplicably ignored Minsky's financial instability hypothesis, which has led many heterodox economists (and some orthodox economists as well) to describe the financial meltdown as a "Minsky moment". Similarly, Fisher's debt-deflation theory of depressions is only mentioned briefly. The arguments developed in this volume could have been considerably reinforced by incorporating a Minsky-Fisher theoretical framework. Despite these reservations, this volume is an original and critical contribution to recent heterodox debates over the critical dynamics of neoliberal globalisation and the growing literature devoted to the phenomenon of financialisation. Indeed, the impressive arsenal of statistical evidence deployed to support the central arguments by the authors makes this volume essential reading.

Bill Lucarelli

University of Western Sydney

\title{
Janice R. Foley and Patricia Baker, Eds. Unions, Equity, and the Path to Renewal (Vancouver: UBC Press, 2010).
}

Unions, Equity, and the Path to Renewal, edited by Janice R. Foley and Patricia Baker, makes a useful contribution in support of the struggle to revitalize the union movement, not least by disputing the argument that equity is a frill that unions, currently under attack and preoccupied with the fight for their very existence, can ill-afford. On the contrary, the contributors - who are remarkably consistent on this point - argue that progress toward equity is essential to union renewal and revitalization. Indeed, they insist that unions have lost much of their former relevance largely because they have failed to support their female and racialized members.

The book, like many others in the genre, is a collaboration between union activists and activist scholars, an approach that links the experience of 
those who have struggled in the trenches with analytically informed research. Chapters by three prominent women unionists, Miriam Edelson, Carol Wall, and Marie Clarke Walker, remind us that women, including many women of colour, have struggled for decades to advance equity within unions. They have formed coalitions with community groups, organized women and workers of colour within unions, and forced their unions to at least acknowledge the presence of workers of colour. In a few cases, they have won structural changes, such as the creation of executive positions for women and members of other equity-seeking groups. But they point out that decades of work have led to only small improvements, most change has been cosmetic, and all too often efforts to advance equity are resisted by union "brothers" who refuse to acknowledge the existence of racism and sexism or to recognize and confront their own privilege.

Clearly, more effective strategies are needed, and this is where scholars can help. In her chapter, Anne Forrest identifies a significant obstacle to change in the decades-long complacency of the organized labour movement that, she argues, has forsaken its role as the "sword of justice" in favour of defending the relative advantages unions have won for their members. In the process, she contends, unions have become vested interests, content to secure a "middle-class lifestyle for the few" - mostly white men in blue-collar jobs - while dismissing women, young, and racialized workers as inherently too hard to organize. The cure for this decline, she proposes, is for unions to re-take their proper place at the heart of social justice struggles, abandoning the institutions that privilege the male industrial workers who no longer form the core of the labour movement. Instead, they must wholeheartedly embrace an equity agenda that focuses on the women, young and racialized workers who are concentrated in service and nonstandard jobs at the core of the economy and who represent the real future of organized labour.

Having established that equity is essential, the book examines efforts by members of equity-seeking groups, most of them women, to advance equity within their unions. Most of the evidence is from public sector unions in Canada, although several chapters consider the U.S., Britain, and Australia, and there is some evidence from private sector unions. But regardless of differences, contributors agree that neither union leaders nor government policies do much to advance equity, that equity-seekers must take action within their own unions, and that activists achieve the best results when they form coalitions, mobilize members specifically around issues that affect them directly, and build alliances with other social justice organizations in the wider community. Linda Briskin, in her chapter, advocates cross-constituency organizing, in which issue-specific groups collaborate but resist efforts by their leaders to amalgamate women's and other groups into single, overarching social justice committees. When they do so, their efforts tend to bog down and members lose impetus and energy. Her conclusion that real rank-and-file energy emanates from coalitions of diverse groups 
resonates with those of the other contributors. Something close to a consensus emerges among the contributors that equity seekers must mobilize among themselves, seek support from union leaders but retain their autonomy, and build strength and solidarity through multiple coalitions with other social justice and equity-seeking groups.

This collection, with its compelling argument that unions can no longer afford to treat equity as an unaffordable luxury, but as critical to their survival, its detailed analyses of the equity strategies that have failed, and its clear and detailed accounts of those that have succeeded, makes a valuable contribution to the literature on union renewal. Those engaged in the struggle to advance equity in their unions would do well to read the book and consider its arguments; they should encourage their union leaders to read it too.

Julie Guard

University of Manitoba

\section{Samuel Moyn, The Last Utopia: Human Rights in History (Cambridge, MA, The Belknap Press of Harvard University Press, 2010).}

Each year my course on "Human Rights in Historical Perspective" begins with an analysis of Adam Hochschild's Bury the Chains (Houghton Mifflin, 2005), and in particular its claim that the British abolitionist campaign was "History's first human rights movement". The students usually decide that it was not, some arguing that it was not the first, others that it was not a human rights campaign at all. Columbia University historian Samuel Moyn would agree with the latter group. In his thought-provoking book Moyn maintains that human rights as a genuine global phenomenon only began in the 1970s, with 1977 the "breakthrough year".

Moyn launches his argument with a disparagement of the historiography that has engaged in a "quixotic search for deep roots" of contemporary human rights. Only very recently have historians (or philosophers, for that matter) sought to trace a consistent trajectory for human rights to the ancient Greeks or Jews, to medieval Christians or Enlightenment scholars or eighteenth century revolutionaries. In the course of his attack, Moyn confronts the prevailing conventions in mainstream historical writing about human rights. Most controversially, perhaps, he dismisses the impact of World War II and the Holocaust, popularly assumed (with considerable academic support) to have generated a reaction that led to the adoption of the Universal Declaration of Human Rights in 1948. Furthermore, he claims, non-governmental organizations had no real hand in introducing human rights to the international agenda in 1945-1948, the Declaration was not cross-cultural in formulation or principles, and it remained 